\title{
PENGEMBANGAN ASESMEN BIOLOGI BERBASIS KETERAMPILAN PROSES SAINS (KPS) DI SMA KOTA PALEMBANG
}

\author{
Cantha Claudhya R.D. ${ }^{1}$ \\ Sri Wardhani ${ }^{2}$ \\ Sulton Nawawi ${ }^{3}$ \\ 1,2,3) Program Studi Pendidikan Biologi, FKIP, Universitas Muhammadiyah Palembang \\ E-mail: ${ }^{1}$ candacrd26@gmail.com ${ }^{2}$ S.wardhaniump@yahoo.com, ${ }^{3}$ Sultonnawawi@um- \\ palembang.ac.id
}

\begin{abstract}
This development research aimed to determine the characteristics and feasibility of the science process skills-based biology assessment for class $X$ on the odd semester material. This assessment was prepared using a research development method adapted from McIntire This development research only wants to see the feasibility stage based on an expert review or expert validation including 3 validators, namely linguists, material experts, and evaluation experts using a questionnaire. The data analysis refers to the score range 1-4 with the feasibility interpretation which is very good, good, not good, and very bad. The results of this development research are in the form of a KPS-based biological assessment in the form of multiple-choice questions as many as 50 questions containing material from odd semesters, namely the scope of biology, biodiversity, viruses, bacteria, and protists. The feasibility assessment was carried out by expert lecturers, for material experts obtained an average percentage of $84 \%$ with a very valid category, linguists obtained an average percentage of $80 \%$ with valid categories, and evaluation experts obtained an average percentage of $95 \%$ with very valid categories so that it can be used to measure science process skills in class $X$ students.
\end{abstract}

Kata kunci: asesmen biologi, keterampilan proses sains, pengembangan

\section{PENDAHULUAN}

Pendidikan merupakan hal yang sangat diperlukan oleh individu untuk mengembangkan kemampuan agar bermanfaat untuk dirinya sendiri dan orang lain. Pendidikan yang dibutuhkan untuk mengembangkan kemampuan individu yaitu pendidikan yang berkualitas. (Anggiasari, Hidayat, \& Harfian, 2018). Pendidikan abad ke-21 juga dikenal dengan masa pengetahuan (knowledge age), sehingga setiap orang dituntut untuk memiliki keterampilan berpikir tingkat tinggi.

Abad ke 21 ini setiap orang harus memiliki keterampilan berpikir tingkat tinggi, pendidikan menjadi semakin penting untuk menjamin peserta didik memiliki keterampilan belajar dan berinovasi, keterampilan menggunakan teknologi dan media informasi, serta dapat bekerja, dan bertahan dengan menggunakan keterampilan untuk hidup (life skills) (Wijaya, Sudjimat, \& Nyoto, 2016).

Keterampilan berpikir tingkat tinggi mencakup beberapa keterampilan salah satunya yaitu Keterampilan Proses Sains (KPS). KPS merupakan seperangkat keterampilan yang digunakan para ilmuwan dalam melakukan penyelidikan ilmiah dengan menggunakan pikiran, nalar dan perbuatan secara efisien dan efektif untuk mencapai suatu hasil tertentu. (Rustaman dkk, 2012). KPS sangat perlu dikuasi oleh peserta didik dalam proses pembelajaran terutama dalam pembelajaran Biologi.

Pembelajaran Biologi peserta didik bukan hanya diberikan pengetahuan melainkan menyiapkan peserta didik 
untuk aktif. Menurut (Asih, 2015) pembelajaran biologi di SMA dirancang untuk menyiapkan, meningkatkan dan juga mengembangkan soft skills dan hard skills yang meliputi aspek kompetensi pengetahuan, sikap, dan juga keterampilan. Aspek pengetahuan dan keterampilan yaitu situasi yang menggiring peserta didik untuk bertanya, mengamati, mengadakan eksperimen, serta menemukan fakta dan konsep sendiri oleh karena itu, dalam pembelajaran Biologi diperlukan cara belajar peserta didik aktif yang mengembangkan KPS.

KPS bisa dinilai atau diukur menggunakan instrumen pengukuran berupa asesmen. Menurut Subali (2012) asesmen merupakan prosedur yang digunakan untuk mendapatkan informasi untuk mengetahui taraf pengetahuan dan keterampilan peserta didik yang hasilnya akan digunakan untuk keperluan evaluasi, sebab dengan adanya asesmen ini, seorang guru bisa mengukur bagaimana perkembangan nilai peserta didik dalam proses pembelajaran di dalam kelas.

Dalam proses pembelajaran siswa dituntut agar turut aktif dan menjadi pusat dalam proses pembelajaran, serta dituntut untuk berpikir, menganalisis, mengevaluasi, dan menyimpulkan sendiri apa yang menjadi permasalahan disetiap materi yang dipelajari guna untuk memecahkan masalah tersebut, guru hanya membimbing, mendorong, dan memberikan fasilitas bagi seorang siswa agar tercapai suatu tujuan pembelajaran (Aseptianova, Nawawi, \& Yuliandina, 2019)

Tugas pendidik adalah mampu mengembangkan keterampilanketerampilan yang dimiliki oleh peserta didik, salah satunya adalah keterampilan proses sains. Iga, Fadiawati, \& Kadaritna (2015) menyatakan bahwa pada kurikulum 2013 asesmen siswa dalam proses pembelajaran sangat erat kaitannya dengan keterampilan berpikir. Keterampilan berpikir siswa dapat dilatih melalui pemberian pengalaman yang bermakna pada proses pembelajaran. Kemampuan berpikir siswa dalam membangun konsep baru pada pembelajaran sains dapat dilatih melalui pengembangan KPS.

Berdasarkan hasil analisis kebutuhan awal dengan menggunakan lembar observasi, wawancara, dan kuesioner pada guru biologi dan peserta didik kelas X di SMA Seberang Ulu 1 dan Seberang Ulu 2 yang terakreditasi A yaitu pada SMA N 19 Palembang, SMA N 8 Palembang, SMA PGRI 2 Palembang, dan SMA Sriguna Palembang, dalam proses pembelajaran biologi kelas $\mathrm{X}$ sudah menerapkan keterampilan proses sains, namun guru belum mengembangkan instrumen atau asesmen berbasis KPS yang sesuai dengan indikator-indikator yang terdapat pada KPS, didapatkan penilaian yang digunakan oleh guru masih mengacu pada aspek pengetahuan. Pada penilaian aspek pengetahuan guru menggunakan instrumen penilaian berbentuk tes berupa pilihan ganda dan esay yang ada pada buku biologi sebagai sumber belajar.

Hasil analisis soal diempat sekolah tersebut juga diketahui bahwa soal berbasis KPS masih tergolong rendah, diperoleh hasil rata-rata yaitu $29,35 \%$ soal yang telah memberdayakan keterampilan proses sains, terdiri dari $6,32 \%$ soal yang mencantumkan indikator mengamati /mengobservasi dengan kategori kurang, $18,02 \%$ soal yang mencantumkan indikator mengelompokkan/klasifikasi dengan kategori kurang, 3,75\% soal yang mencantumkan indikator meramalkan /prediksi dengan kategori kurang 2,50\% soal yang mencantumkan indikator merencanakan percobaaan/penelitian dengan kategori kurang dan $0 \%$ untuk soal dengan indikator menafsirkan /interpretasi, mengajukan pertanyaan, berhipotesis, menerapkan konsep dan berkomunikasi. Sehingga perlu untuk mengembangkan asesmen KPS di SMA 
tersebut sebagai alat untuk mengungkap

\section{METODE}

Penelitian ini adalah peneltian pengembangan atau Development Research. Tujuan penelitian pengembangan ini digunakan untuk menghasilkan produk. Untuk menguji keefektifan hasil produk maka diperlukan penelitian untuk kelayakan produk tersebut.

Pada penelitian ini produk yang dikembangkan adalah soal pilihan ganda berbasis keterampilan proses sains (KPS) materi biologi di kelas $\mathrm{X}$ semester ganjil dengan materi Ruang Lingkup Biologi, Keanekaragaman Hayati, Virus, Bakteri, dan Protista.

Penelitian ini menggunakan model penelitian pengembangan menurut McIntire dalam Mulyatiningsih (2011), terdapat 10 langkah pengembangan tes yang harus dilalui yaitu: mendefinisikan kompetensi, peserta tes, dan tujuan tes (defining the test universe, audience, and purpose), mengembangkan rencana uji (developing a test plan), menyusun item tes (composing the test items), menulis instruksi administrasi (writing the administration instructions), melakukan uji coba (conduct piloting test), analisis item (item analysis), merevisi tes (revising the test), validasi tes (validation the test), mengembangkan norma (developing norms), lengkapi tes manual (complete test manual)

Tahap yang dilaksanakan hanya sampai pada tahapan ke empat yaitu menulis instruksi adminstrasi dikarenakan penulis hanya ingin melihat karakteristik dan kelayakan instrumen asesmen biologi yang dibuat dalam alur pelaksanaan strategi penelitian pengembangan.

Langkah pertama yaitu mendefinisikan kompetensi, peserta tes, dan tujuan tes (defining the test universe, audience, and purpose). Tes yang akan dikembangkan dalam penelitian ini adalah soal pilihan ganda. Menyusun kisi-kisi tes untuk mengukur keterampilan proses sains proses dan kemajuan belajar peserta didik.

pada materi semester ganjil. Dalam kisikisi yang dikembangkan memuat gambaran antara indikator keterampilan proses sains terkait konten materi dan butir soal. Penyusunan tes dalam penelitian ini berdasar pada kisi-kisi. Instrumen penilaian Keterampilan Proses Sains (KPS) terdapat 50 soal pilihan ganda.

Tujuan dari penggunaan tes ini sebagai alat ukur oleh guru dalam menilai keterampilan proses sains peserta didik pada materi yang telah disebutkan dan sebagai referensi bagi guru, sekolah, serta peneliti lain dalam menyusun dan mengembangkan asesmen biologi. Tujuan penggunaan bagi peserta didik adalah untuk meningkatkan keterampilan proses sains. Pengguna dari tes ini adalah guru Biologi dan peserta didik kelas X IPA.

Langkah kedua yaitu mengembangkan rencana uji (developing a test plan. Hal-hal yang direncanakan dalam tahap ini meliputi konstruk (kisikisi), format pertanyaan atau jawaban, bentuk penyelenggaraan dan cara penyekorannya. Kisi-kisi dibuat dari Kompetensi Dasar (KD) materi Biologi kelas X semester 1 dari Permendikbud No. 37 Tahun 2018.Instrumen penilaian berupa soal pilihan ganda dengan pilihan jawaban A, B, C, D dan E.

Langkah ketiga yaitu menyusun item tes (composing the test items). Soal Keterampilan proses sains yang akan diujikan sebanyak 50 butir soal pilihan ganda. Instrumen yang digunakan pada validasi ahli (expert judgment), validasi dilakukan oleh 3 validator ahli: (1) ahli materi; (2) ahli bahasa; dan (3) ahli evaluasi. Di dalam melakukan telaah instrumen, maka fokusnya adalah suatu instrumen telah memenuhi persyaratan yang telah ditetapkan.

Langkah keempat yaitu menulis instruksi administrasi (writing the administration instructions). Pada tahap ini disusun petunjuk penyelenggaraan tes 
yang terdiri dari petunjuk untuk penyelenggara dan pengawas ujian serta petunjuk untuk peserta tes itu sendiri. Petunjuk penyelenggaraan yang digunakan dalam penelitian ini berisikan kondisi yang harus disiapkan pada saat tes dilaksanakan.

Teknik analisis data dilakukan untuk mengetahui kelayakan asesmen yang dikembangkan. Dilakukan pengisian lembar validasi yang dilakukan oleh dosen ahli dengan menggunakan skala likert berdasarkan Tabel 1. sebagai berikut.

Tabel 1. Pedoman penskoran pada angket (Skala Likert)

\begin{tabular}{ccc}
\hline No. & Analisis Kuantitatif & Skor \\
\hline 1. & Sangat Baik & 4 \\
\hline 2. & Baik & 3 \\
\hline 3. & Tidak Baik & 2 \\
\hline 4. & Sangat Tidak Baik & 1 \\
\hline
\end{tabular}

(Sugiyono, 2018)

Menghitung persentase jawaban dari setiap pernyataan pada instrumen validasi dan angket dengan menggunakan rumus berikut:

Persentase Jawaban Responden $=\frac{\text { jumlah skor } \text { yang diperoleh }}{\text { jumlah skor tertinggi }} \times 100$

(Sugiyono, 2018: 137)

Persentase kelayakan yang didapatkan kemudian diinterpretasikan kedalam kategori berdasarkan Tabel 2. berikut:

Tabel 2. Kategori Kelayakan

\begin{tabular}{cc}
\hline Skor rata-rata & Kategori \\
\hline$<81,25 \%-100 \%$ & Sangat Valid \\
\hline$<62,5 \%-81,25 \%$ & Valid \\
\hline$<43,75 \%-62,5 \%$ & Tidak Valid \\
\hline $25 \%-43,75 \%$ & Sangat Tidak \\
& Valid \\
\hline (Riduwan 2015$)$ &
\end{tabular}

Tafsiran hasil validasi ini digunakan untuk menentukan kevalidan (kelayakan) instrumen asesmen yang dikembangkan. Asesmen dinyatakan valid secara teoritis apabila persentase kelayakannya adalah $62,5 \%$.

\section{HASIL}

Tabel 3. Kisi-Kisi Soal

\begin{tabular}{llcc}
\hline \multicolumn{1}{c}{ Kompetensi Dasar } & \multicolumn{1}{c}{ Indikator KPS } & Nomor Soal & Kunci Jawaban \\
\hline 3.1 Memahami melalui & Mengamati & 1 & $\mathrm{~A}$ \\
penerapan tentang ruang & Mengelompokkan & 2 & $\mathrm{D}$ \\
lingkup Biologi & Menafsirkan & 3 & $\mathrm{C}$ \\
(permasalahan pada berbagai & Meramalkan & 4 & $\mathrm{D}$ \\
obyek Biologi dan tingkat & Mengajukan pertanyaan & 5 & $\mathrm{~B}$ \\
organisasi kehidupan), & Berhipotesis & 6 & $\mathrm{~B}$ \\
metode ilmiah dan prinsip & Merencanakan & 7 & $\mathrm{C}$ \\
keselamatan kerja & percobaan & & $\mathrm{C}$ \\
berdasarkan pengamatan dan & Menerapkan konsep & 8 & $\mathrm{E}$ \\
percobaan, kompetensi dasar & Berkomunikasi & 9 & $\mathrm{~A}, \mathrm{~B}$ \\
\hline 3.2 Menganalisis data hasil & Mengamati & 11,12 & $\mathrm{C}$ \\
observasi tentang berbagai & Mengelompokkan & 13 & $\mathrm{D}$ \\
tingkat keanekaragaman & Menafsirkan & 14 & $\mathrm{D}$ \\
hayati (gen, jenis dan & Meramalkan & 15 & $\mathrm{~B}$ \\
ekosistem), di Indonesia & Mengajukan pertanyaan & 16 & - \\
serta ancaman dan & Berhipotesis & - & $\mathrm{A}$ \\
pelestariannya, kompetensi & Merencanakan & 17 & $\mathrm{C}$ \\
dasar & percobaan & 18 & $\mathrm{E}$ \\
\hline
\end{tabular}




\begin{tabular}{|c|c|c|c|}
\hline Kompetensi Dasar & Indikator KPS & Nomor Soal & Kunci Jawaban \\
\hline \multirow{9}{*}{$\begin{array}{l}\text { 3.3 Memahami prinsip- } \\
\text { prinsip klasifikasi makhluk } \\
\text { hidup dalam lima kingdom, } \\
\text { kompetensi dasar }\end{array}$} & Mengamati & 20 & $\mathrm{C}$ \\
\hline & Mengelompokkan & 21,25 & $\mathrm{D}, \mathrm{B}$ \\
\hline & Menafsirkan & 22 & $\mathrm{D}$ \\
\hline & Meramalkan & - & - \\
\hline & Mengajukan pertanyaan & 24 & A \\
\hline & Berhipotesis & - & - \\
\hline & $\begin{array}{l}\text { Merencanakan } \\
\text { percobaan }\end{array}$ & 23 & $\mathrm{C}$ \\
\hline & Menerapkan konsep & - & - \\
\hline & Berkomunikasi & - & - \\
\hline \multirow{9}{*}{$\begin{array}{l}\text { 3.4 Menganalisis struktur } \\
\text { dan replikasi, serta peran } \\
\text { virus dalam aspek kesehatan } \\
\text { masyarakat, kompetensi } \\
\text { dasar }\end{array}$} & Mengamati & 26 & A \\
\hline & Mengelompokkan & 27 & B \\
\hline & Menafsirkan & 30 & $\mathrm{D}$ \\
\hline & Meramalkan & 31 & A \\
\hline & Mengajukan pertanyaan & - & - \\
\hline & Berhipotesis & - & - \\
\hline & $\begin{array}{l}\text { Merencanakan } \\
\text { percobaan }\end{array}$ & 29 & B \\
\hline & Menerapkan konsep & 28 & $\mathrm{D}$ \\
\hline & Berkomunikasi & 32 & $\mathrm{C}$ \\
\hline \multirow{9}{*}{$\begin{array}{l}\text { 3.5 Menganalisi struktur dan } \\
\text { cara hidup bakteri serta } \\
\text { perannya dalam berbagai } \\
\text { aspek kehidupan masyarakat } \\
\text { dan kompetensi dasar }\end{array}$} & Mengamati & 33 & B \\
\hline & Mengelompokkan & 34 & A \\
\hline & Menafsirkan & 35 & B \\
\hline & Meramalkan & 38,40 & $\mathrm{~A}, \mathrm{C}$ \\
\hline & Mengajukan pertanyaan & 39 & A \\
\hline & Berhipotesis & 36,37 & $\mathrm{C}, \mathrm{D}$ \\
\hline & $\begin{array}{l}\text { Merencanakan } \\
\text { percobaan }\end{array}$ & 41,43 & $\mathrm{C}, \mathrm{B}$ \\
\hline & Menerapkan konsep & - & - \\
\hline & Berkomunikasi & 42 & $\mathrm{C}$ \\
\hline 3.6 Menerapkan prinsip & Mengamati & 44 & $\mathrm{D}$ \\
\hline klasifikasi untuk & Mengelompokkan & 45 & $\mathrm{C}$ \\
\hline menggolongkan protista & Menafsirkan & - & - \\
\hline berdasarkan ciri-ciri umum & Meramalkan & 49 & $\mathrm{C}$ \\
\hline kelas dan perannya dalam & Mengajukan pertanyaan & - & - \\
\hline kehidupan melalui & Berhipotesis & 48 & A \\
\hline \multirow{3}{*}{$\begin{array}{l}\text { pengamatan secara teliti dan } \\
\text { sistematis }\end{array}$} & Merencanakan & 46 & B \\
\hline & Menerapkan konsep & 47 & A \\
\hline & Berkomunikasi & 50 & B \\
\hline
\end{tabular}

Tabel 4. Contoh Soal Keterampilan Proses Sains (KPS)

\begin{tabular}{|c|c|c|c|}
\hline Kompetensi Dasar (KD) & $\begin{array}{c}\text { Indikator Keterampilan } \\
\text { Proses Sains (KPS) }\end{array}$ & Soal & Jawaban \\
\hline $\begin{array}{l}\text { 3.1 Memahami melalui } \\
\text { penerapan tentang } \\
\text { ruang lingkup } \\
\text { Biologi } \\
\text { (permasalahan pada } \\
\text { berbagai obyek } \\
\text { Biologi dan tingkat } \\
\text { organisasi } \\
\text { kehidupan), metode } \\
\text { ilmiah dan prinsip } \\
\text { keselamatan kerja } \\
\text { berdasarkan } \\
\text { pengamatan dan } \\
\text { percobaan }\end{array}$ & Mengamati & $\begin{array}{l}\text { 1. Peserta didik kelas } \mathrm{X} \text { sedang } \\
\text { mengamati gambar tingkat organisasi } \\
\text { kehidupan. Artinya, mereka sedang } \\
\text { mempelajari objek } \\
\text { biologi. } \\
\text { Urutkanlah tingkatan organisasi } \\
\text { kehidupan dari yang terkecil sampai }\end{array}$ & $\mathrm{a}$ \\
\hline
\end{tabular}




\begin{tabular}{|c|c|c|c|}
\hline & & $\begin{array}{l}\text { terbesar pada gambar di atas dengan } \\
\text { benar... } \\
\text { a. } 3-5-7-1-8-2-6-4 \\
\text { b. } 1-3-2-6-5-4-7-8 \\
\text { c. } 2-3-1-6-5-8-7-4 \\
\text { d. } 3-2-1-7-5-4-6-8 \\
\text { e. } 1-4-2-3-6-8-5-7\end{array}$ & \\
\hline $\begin{array}{l}\text { 3.2 } \text { Menganalisis data } \\
\text { hasil observasi } \\
\text { tentang berbagai } \\
\text { tingkat } \\
\text { keanekaragaman } \\
\text { hayati (gen, jenis dan } \\
\text { ekosistem) di } \\
\text { Indonesia serta } \\
\text { ancaman dan } \\
\text { pelestariannya }\end{array}$ & Mengelompokkan & $\begin{array}{l}\text { 13. Gurun merupakan padang luas yang } \\
\text { tandus karena hujan sangat jarang } \\
\text { turun di daerah tersebut. Contohnya } \\
\text { gurun Gobi di Asia dan gurun Sahara } \\
\text { di Afrika. Perhatikanlah ciri-ciri di } \\
\text { bawah ini! } \\
\text { 1. Curah hujan sangat rendah, } \\
\text { kurang dari } 25 \mathrm{~cm} / \text { tahun } \\
\text { 2. Memiliki Vegetasi Tanaman } \\
\text { Berlapis } \\
\text { 3. Memiliki Pohon Tinggi Berdaun } \\
\text { 4ebat } \\
\text { Delembapan udara sangat rendah } \\
\text { yang benar terdapat pada nomor... } \\
\text { a. } 1 \text { dan } 2 \\
\text { b. } 1 \text { dan } 3 \\
\text { c. } 1 \text { dan } 4 \\
\text { d. } 2 \text { dan } 3 \\
\text { e. } 3 \text { dan } 4\end{array}$ & $\mathrm{c}$ \\
\hline $\begin{array}{l}3.4 \text { Menganalisis struktur } \\
\text { dan replikasi, serta } \\
\text { peran virus dalam } \\
\text { aspek kesehatan } \\
\text { masyarakat }\end{array}$ & Menafsirkan & 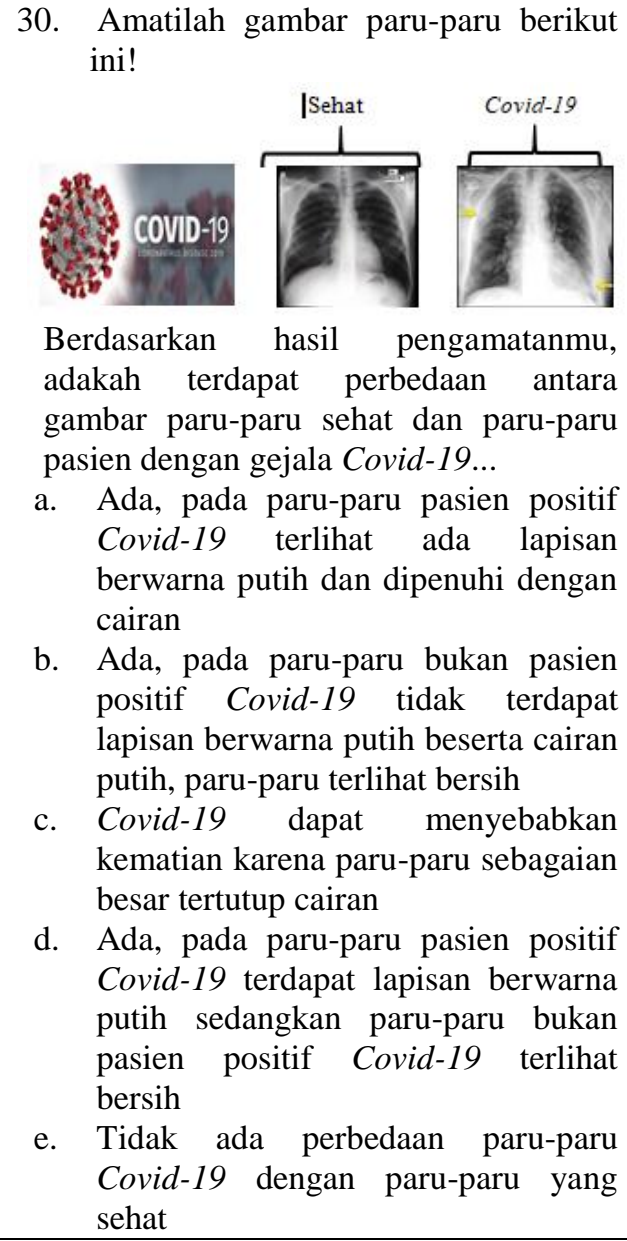 & $\mathrm{d}$ \\
\hline $\begin{array}{c}\text { 3.6 Menerapkan prinsip } \\
\text { klasifikasi untuk }\end{array}$ & Meramalkan & $\begin{array}{l}\text { 49. Lisa mengobservasi air dari sebuah } \\
\text { tambak ikan. Observasi diketahui }\end{array}$ & $\mathrm{d}$ \\
\hline
\end{tabular}




\begin{tabular}{|c|c|c|c|}
\hline $\begin{array}{l}\text { menggolongkan } \\
\text { protista berdasarkan } \\
\text { ciri-ciri umum kelas } \\
\text { dan perannya dalam } \\
\text { kehidupan melalui } \\
\text { pengamatan secara } \\
\text { teliti dan sistematis }\end{array}$ & & $\begin{array}{l}\text { bahwa protista mirip jamur } \\
\text { (Oomycota) dapat merugikan } \\
\text { manusia, apabila Oomycota tidak } \\
\text { cepat ditanggulangi maka akan } \\
\text { mengakibatkan penurunan populasi } \\
\text { pada... } \\
\text { a. Zooplankton } \\
\text { b. Fitoplankton } \\
\text { c. Ikan } \\
\text { d. Hydra } \\
\text { e. Bakteri pengurai }\end{array}$ & \\
\hline $\begin{array}{l}\text { 35. Menganalisis struktur } \\
\text { dan cara hidup bakteri } \\
\text { serta perannya dalam } \\
\text { berbagai aspek } \\
\text { kehidupan masyarakat }\end{array}$ & Mengajukan pertanyaan & $\begin{array}{l}\text { 39. Pertanyaan yang tepat untuk gambar } \\
\text { di bawah ini adalah... } \\
\text { a. Apakah infeksi bakteri dapat } \\
\text { menyebakan penyakit bagi } \\
\text { manusia? } \\
\text { b. Apakah ada perbedaan dari } \\
\text { beberapa macam bakteri? } \\
\text { c. Bagaimana cara bakteri dapat } \\
\text { menginfeksi manusia? } \\
\text { d. Mengapa bakteri dapat hidup } \\
\text { pada tubuh manusia? } \\
\text { e. Berapa banyak bakteri yang dapat } \\
\text { menyebabkan penyakit pada } \\
\text { manusia? }\end{array}$ & \\
\hline $\begin{array}{ll}3.5 & \text { Menganalisis } \\
& \text { struktur dan cara } \\
& \text { hidup bakteri serta } \\
\text { perannya dalam } \\
\text { berbagai aspek } \\
\text { kehidupan } \\
\text { masyarakat }\end{array}$ & Berhipotesis & 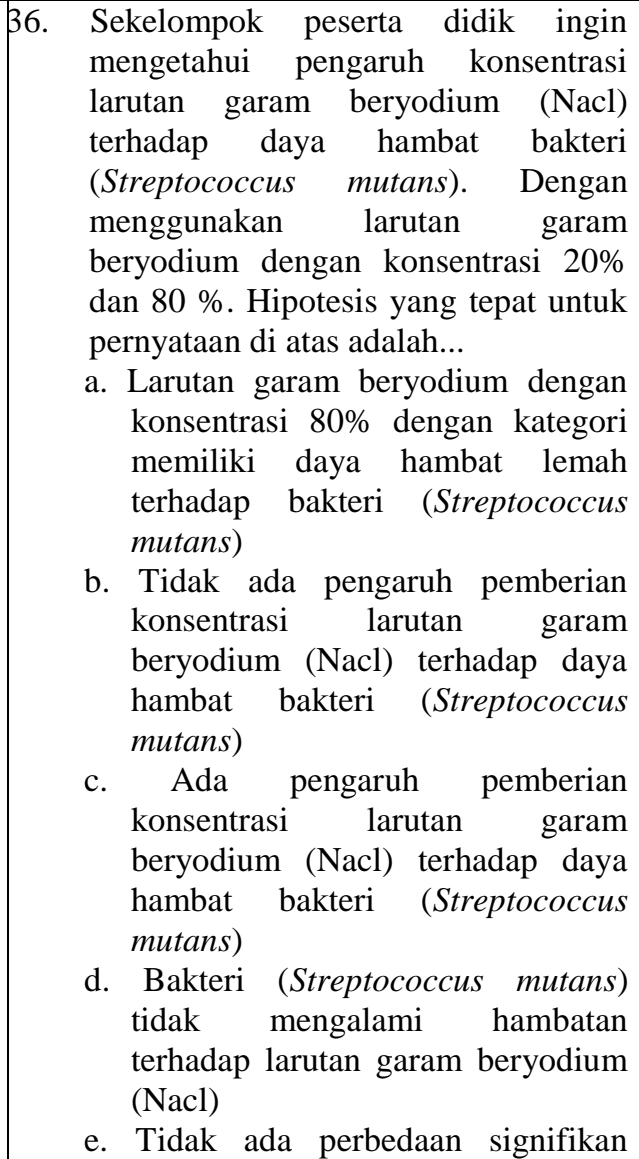 & $\mathrm{c}$ \\
\hline
\end{tabular}




\begin{tabular}{|c|c|c|c|c|c|}
\hline & & \multicolumn{3}{|c|}{$\begin{array}{l}\text { antara larutan garam dengan } \\
\text { konsentrasi } 20 \% \text { dan } 80 \% \text { dalam } \\
\text { menghambat pertumbuhan bakteri } \\
\text { Streptococcus mutans. }\end{array}$} & \\
\hline $\begin{array}{l}\text { 3.3 Memahami prinsip- } \\
\text { prinsip klasifikasi } \\
\text { makhluk hidup } \\
\text { dalam lima kingdom }\end{array}$ & Merencanakan percobaan & \multicolumn{3}{|c|}{$\begin{array}{l}\text { 23. Seorang peserta didik ingin melakukan } \\
\text { percobaan untuk membuat kladogram } \\
\text { untuk mengetahui kingdom plantae. } \\
\text { Berdasarkan tema penelitian yang } \\
\text { telah diuraikan, alat dan bahan yang } \\
\text { tepat digunakan untuk percobaan } \\
\text { tersebut adalah... } \\
\text { a. Alat tulis dan tumbuhan } \\
\text { b. Kertas HVS dan tumbuhan } \\
\text { c. Alat tulis dan kertas HVS atau } \\
\text { d. Kerton HVS dan plastisin } \\
\text { e. Plastisin dan stopwatch }\end{array}$} & $\mathrm{c}$ \\
\hline $\begin{array}{l}\text { 3.2 } \text { Menganalisis data } \\
\text { hasil observasi } \\
\text { tentang berbagai } \\
\text { tingkat } \\
\text { keanekaragaman } \\
\text { hayati (gen, jenis dan } \\
\text { ekosistem) di } \\
\text { Indonesia serta } \\
\text { ancaman dan } \\
\text { pelestariannya }\end{array}$ & Menerapkan konsep & \multicolumn{3}{|c|}{ 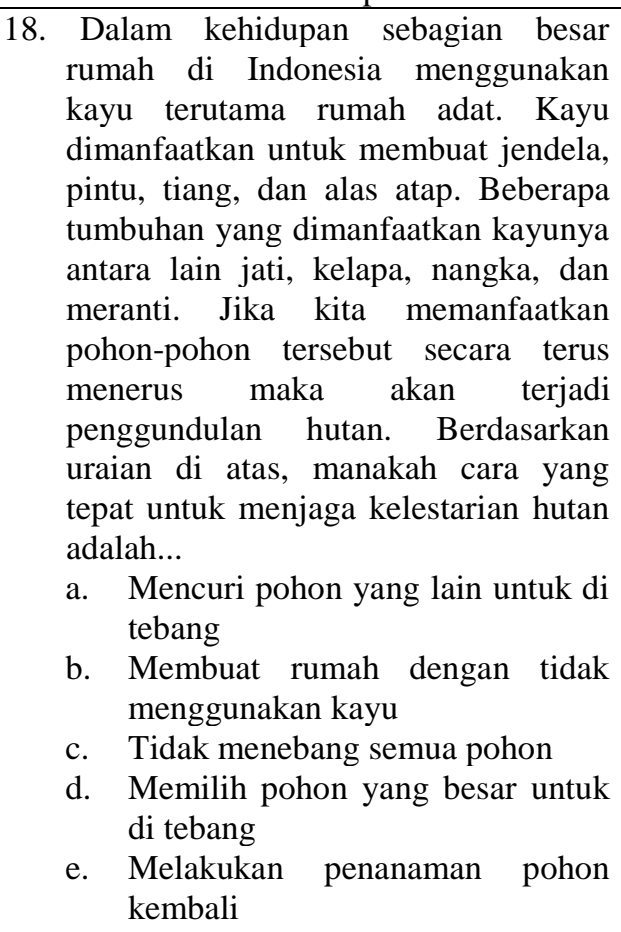 } & e \\
\hline \multirow{10}{*}{$\begin{array}{l}\text { 3.1 Memahami melalui } \\
\text { penerapan tentang ruang } \\
\text { lingkup Biologi } \\
\text { (permasalahan pada } \\
\text { berbagai obyek Biologi } \\
\text { dan tingkat organisasi } \\
\text { kehidupan), metode } \\
\text { ilmiah dan prinsip } \\
\text { keselamatan kerja } \\
\text { berdasarkan pengamatan } \\
\text { dan percobaan }\end{array}$} & \multirow[t]{10}{*}{ Berkomunikasi } & \multicolumn{3}{|c|}{$\begin{array}{l}\text { 9. Perhatikan tabel di bawah ini! } \\
\text { Tabel distribusi frekuensi dan presentase } \\
\text { kejadian kecelakaan kerja di } \\
\text { laboratorium. }\end{array}$} & \\
\hline & & \begin{tabular}{|c|c|} 
No & \multicolumn{1}{|c|}{ Jenis kecelakaan } \\
1 & $\begin{array}{l}\text { Terkena tumpahan } \\
\text { bahan kimia }\end{array}$ \\
\end{tabular} & $\begin{array}{c}\text { Frekuensi } \\
20\end{array}$ & \begin{tabular}{|c|} 
Presentase \\
66.66
\end{tabular} & \\
\hline & & \begin{tabular}{l|l}
2 & Tejjatuh atau terpeleset \\
3 & Kontak dengan panas \\
\end{tabular} & 2 & 6.66 & \\
\hline & & \begin{tabular}{|l|lr}
4 & $\begin{array}{l}\text { Terkena } \\
\text { glassware }\end{array}$ & pecahaan \\
\end{tabular} & 1 & 3.33 & \\
\hline & & Terkena sengatan listrik & 4 & 13.33 & \\
\hline & & \begin{tabular}{l|l|}
6 & $\begin{array}{l}\text { Mata } \\
\text { kimia }\end{array}$
\end{tabular} & 6 & 20.00 & \\
\hline & & \begin{tabular}{|l|} 
Kebakaran \\
\end{tabular} & 1 & 3.33 & \\
\hline & & Peledakan & 4 & 13.33 & \\
\hline & & \begin{tabular}{|l|} 
Initasi kulit \\
\end{tabular} & 19 & 63.33 & \\
\hline & & \begin{tabular}{|l|} 
Keluhan pusing \\
\end{tabular} & 20 & 66.66 & \\
\hline
\end{tabular}




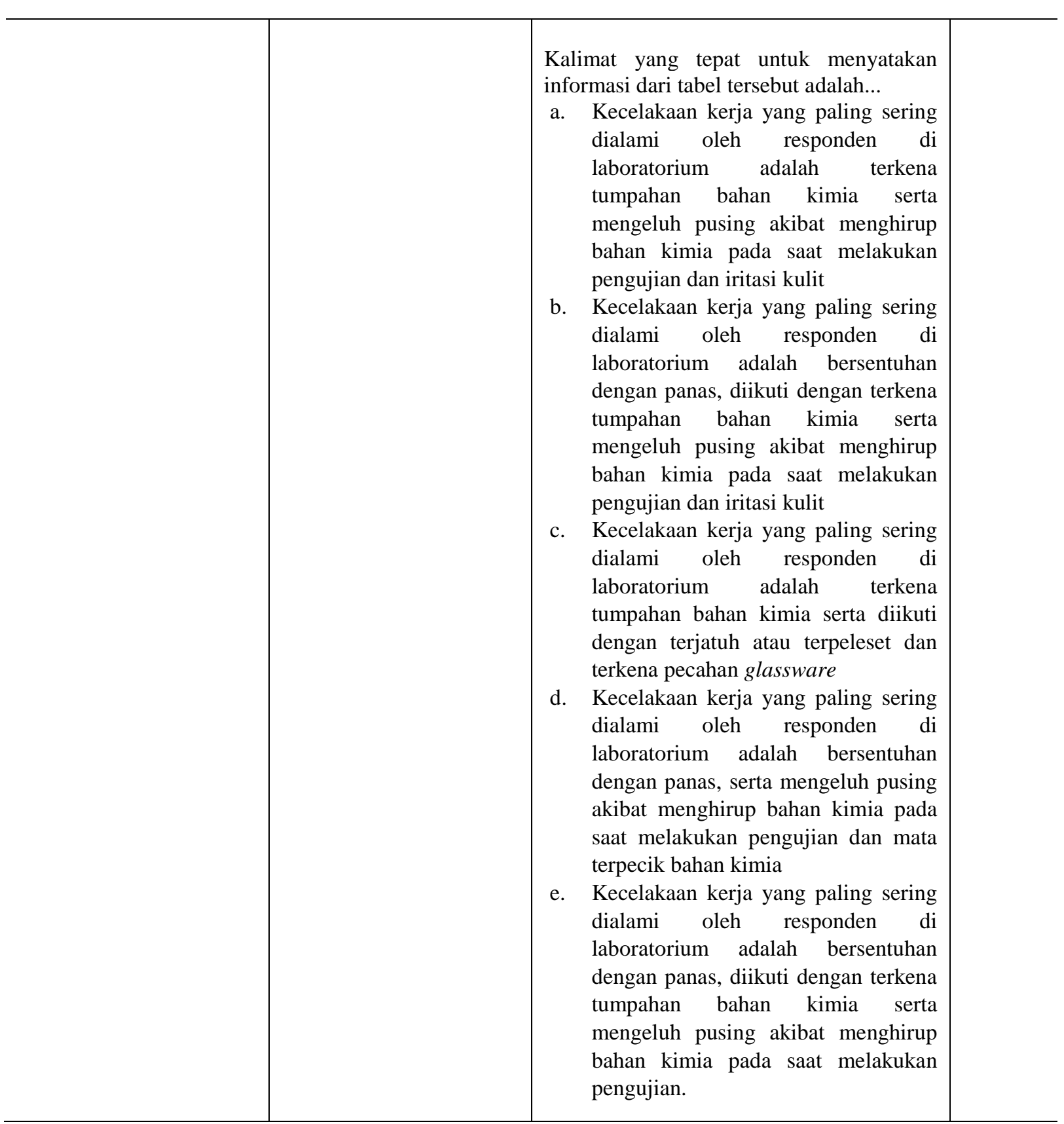

Tabel 5. Hasil Rata-rata Penilaian Validasi Ahli

\begin{tabular}{|c|c|c|c|c|c|c|}
\hline \multirow[t]{2}{*}{ No } & \multirow[t]{2}{*}{ Aspek yang dinilai } & \multicolumn{2}{|c|}{ Penilaian } & \multirow{2}{*}{$\begin{array}{c}\text { Persentase } \\
\text { skor rata-rata } \\
(\%)\end{array}$} & \multirow[t]{2}{*}{ Kualifikasi } & \multirow[t]{2}{*}{ Kategori } \\
\hline & & $\begin{array}{c}\text { Validator } \\
1\end{array}$ & $\begin{array}{c}\text { Validator } \\
2\end{array}$ & & & \\
\hline 1 & Aspek materi & 15 & 12 & 84 & Sangat valid & $\begin{array}{c}\text { Tidak perlu } \\
\text { direvisi }\end{array}$ \\
\hline 2 & Aspek Bahasa & 15 & 17 & 80 & Valid & $\begin{array}{l}\text { Tidak perlu } \\
\text { direvisi }\end{array}$ \\
\hline 3 & Aspek evaluasi & 78 & 83 & 95 & Sangat valid & $\begin{array}{c}\text { Tidak perlu } \\
\text { direvisi }\end{array}$ \\
\hline
\end{tabular}

Hasil validasi ahli materi, ahli bahasa dan ahli evaluasi asesmen biologi berbasis keterampilan proses sains (KPS) dapat dilihat pada Tabel 5. Hasil penilaian validator materi, dan evaluasi tentang asesmen berbasis keterampilan proses sains (KPS) berkualifikasi sangat valid sehingga layak digunakan, 
semetara utuk penilaian validator Bahasa tentang asesmen berbasis keterampilan proses sains (KPS) berkualifikasi valid sehingga layak digunakan. Hasil sangat valid dan valid bukan berarti tidak ada lagi revisi guna untuk kebaikan asesmen yang dikembangkan ada beberapa saran dan masukan untuk diperbaiki seperti tata tulis, ejaan yang baik dan benar, panjang kunci jawaban yang tidak sama, soal lebih disesuaikan dengan indikator KPS dan silabus Permendikbud No. 37 Tahun 2018.

Saran dan masukan dari validator materi, bahasa, dan evaluasi sudah diperbaiki oleh peneliti kemudian dilanjutkan pada tahap keempat yaitu menulis instruksi adminstrasi (Writting the adminstration instruction) yaitu membuat petunjuk penyelenggaraan tes yang terdiri dari petunjuk untuk penyelenggara, pengawas ujian dan petunjuk untuk peserta tes itu sendiri.

\section{PEMBAHASAN}

\section{Karakteristik Soal Biologi Berbasis Keterampilan Proses Sains (KPS) di SMA Kota Palembang pada Semester Ganjil}

Asesmen dikembangkan dengan mengacu pada kompetensi dasar materi Biologi kelas $\mathrm{X}$ semester 1 dari Permendikbud No. 37 Tahun 2018, kemudian materi dikaitkan dengan indikator ketetampilan proses sains menurut Rustaman (2012) yang terdiri dari 9 indikator yaitu mengamati, mengelompokkan,menafsirkan,

meramalkan, mengajukan pertanyaan, berhipotesis, merencanakan percobaan, menerapkan konsep, dan berkomunikasi.

Asesmen yang dikembangkan sudah sesuai dengan kriteria kelengkapan instrumen asesmen. Soal yang dikembangkan disesuaikan dengan prosedur pengembangan alat ukur. Hal ini sejalan dengan Subali (2012) diperlukan adanya alat atau instrumen penilaian yang dipakai dalam kegiatan pengukuran atau yang disebut alat ukur.
Alat ukur ada yang berupa tes dan non tes, agar diperoleh alat penilain atau alat ukur yang baik perlu dikembangkan suatu prosedural pengembangan alat penilaian yang meliputi perencanaan penilaian yang memuat maksud dan tujuan penelitian, penyusunan kisi-kisi, penyusunan instrumen/alat ukur, penelahan (review) untuk menilai kualitas alat ukur/instrumen secara kualitatif sebelum digunakan, uji coba alat ukur, untuk menyelidiki kesahihan dan keandalan secara empiris, pelaksanaan pengukuran, penilaian yang merupakan interpretasi hasil pengukuran dan pemanfaatan hasil asesmen.

Asesmen yang dikembangkan yaitu pada materi Ruang Lingkup Biologi, Keanekaragaman Hayati, Virus, Bakteri, dan Protista yang bertujuan sebagai alat ukur oleh tenaga pendidik dalam menilai keterampilan proses sains bagi peserta didik, sebagai referensi soal keterampilan proses sains bagi guru, serta bagi peneliti lain yang sedang dalam tahap menyusun dan mengembangkan asesmen biologi berbasis keterampilan proses sains.

Soal KPS yang dibuat mengarahkan peserta didik untuk tidak hanya menguasai keterampilan kognitif saja tetapi juga keterampilan psikomotor, dan keterampilan afektif yang digunakan untuk mengembangkan keterampilanketerampilan dasar sains, sikap ilmiah dan sikap kritis peserta didik. Hal ini sejalan dengan Rustaman, (2005) yang menjelaskan bahwa keterampilan proses sains melibatkan keterampilan kognitif, manual dan sosial, kognitif terlibat karena dengan melakukan keterampilan proses sains peserta didik akan menggunakan pikiranya, keterampilan manual jelas terlibat dalam keterampilan proses sains karena mereka melibatkan penggunaan alat dan bahan, pengukuran, penyusunan, atau perakitan alat.

$$
\text { Asesmen KPS yang dibuat }
$$
mendorong peserta didik untuk memahami bagaimana cara untuk 


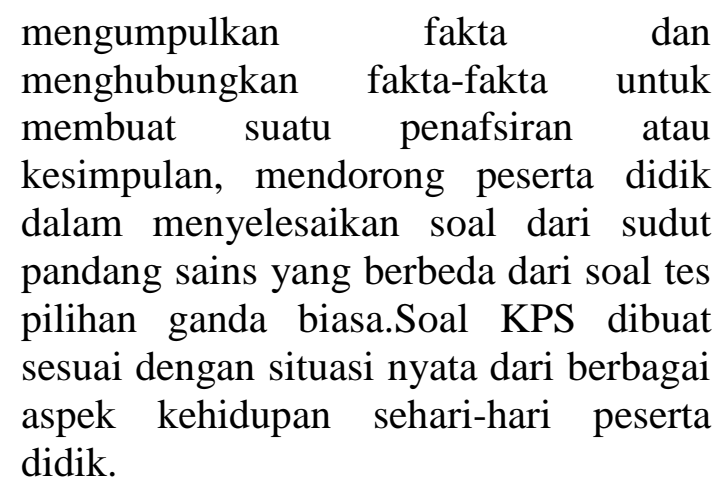

Soal KPS perlu dilatihkan atau dikembangkan dalam pembelajaran biologi karena peserta didik tidak hanya mempelajari apa yang sudah ada tetapi siswa juga belajar bagaimana memperoleh pengetahuan tersebut. Selain itu pada soal KPS, peserta didik dituntut lebih aktif dan kreatif dalam memecahkan masalah dan menghubungkan pola-pola penelitian untuk menyelesakan suatu permasalahan menuntut peserta didk untuk menjawab pertanyaan tidak hanya berdasarkan pengetahuannya saja, dan menuntut peserta didik untuk mengerjakan soal yang termasuk ke dalam soal HOTS (Higher Order Thinking Skill) atau soal yang menuntut peserta didik untuk berfikir tingkat tinggi, sehingga peserta didik nantinya diharapkan dapat menyelesakan sendiri permasalahan dan memberikan solusi untuk masalah yang terjadi dalam kehidupan sehari-harimereka. Hal ini juga diungkapkan oleh (Khairunnisa, Ita, \& Istiqamah, 2019). Keterampilan proses didapat bukan hanya dalam sekejap namun soft skill ini didapat dari pembiasaan yang sering dilakukan dalam pembelajaran sehari-har, sehingga KPS juga mempunyai peran untuk mengarahkan peserta didik untuk menguasai materi atau kognitifnya tetapi dapat juga mengembangkan pikirannya, memberi kesempatan kepada peserta didik untuk melakukan penemuan, serta dapat membantu peserta didik mempelajari konsepkonsep sains.

\begin{abstract}
Kelebihan Produk asesmen biologi berbasis KPS yang telah dikembangkan ini berbeda dengan soal pada umumnya, soal yang dikembangkan mengacu pada indikator KPS dan dapat mengukur kemampuan peserta didik dalam mengamati, mengelompokkan, menafsirkan meramalkan, mengajukan pertanyaan, berhipotesis, menerapkan konsep, merencanakan percobaan, dan berkomunikasi, soal ini dalam pengembanganya juga dikaitkan dengan silabus Permendikbud No.37 Tahun 2018 serta soal yang dikembangkan berupa soal pada semester ganjil kelas $\mathrm{X}$ yaitu materi ruang lingkup biologi, keanekaragaman hayati, bakteri, virus, dan protista. Soal ini juga tidak hanya menuntut peserta didik untuk menguasai materisaja tetapi peserta didik juga dapat mengembangkan pikirannya, memberi kesempatan kepada peserta didik untuk melakukan penemuan dari pola-pola hasil penelitian yang diamati, serta dapat membantu peserta didik mempelajari konsep-konsep sains, menuntut peserta didik untuk mengerjakan soal yang termasuk ke dalam soal HOTS atau soal yang menuntut peserta didik untuk berfikir tingkat tinggi, sehingga peserta didik terlatih untuk menyelesaikan soal berfikir tingkat tinggi dan nantinya diharapkan dapat menyelesakan sendiri permasalahan dan memberikan solusi untuk masalah yang terjadi dalam kehidupan sehari-hari mereka.
\end{abstract}

\section{Kelayakan Soal Biologi Berbasis Keterampilan Proses Sains (KPS) di SMA Kota Palembang pada Semester Ganjil}

Kelayakan dari asesmen biologi berbasis KPS di SMA kota Palembang ini dinilai berdasarkan penilaian dari 6 orang dosen validator yang masingmasing terdiri dari 2 orang ahli materi, 2 orang ahli bahasa, dan 2 orang ahli evaluasi. Berikut ini merupakan hasil 
kelayakan dari asesmen biologi berbasis KPS pada materi biologi kelas $\mathrm{X}$ di SMA kota Palembang.Berdasarkan hasil expert judgment untuk validasi materi diperoleh persentase skor rata-rata $84 \%$ dengan kategori sangat valid, validasi bahasa diperoleh persentase skor ratarata $80 \%$ dengan kategori valid, validasi evaluasi di peroleh persentase skor $95 \%$ yang menunjukkan kategori sangat valid.

$$
\text { Penilaian ahli materi }
$$

memberikan saran dan kritik berupa sesuaikan gambar dengan materi kemudian dilakukan perbaikan pada gambar yang kurang jelas. Gambar yang kurang jelas dapat menimbulkan banyak penafsiran bagi peserta didik dalam memahami maksud dan makna yang disampaikan pada soal oleh karena itu validator menyarankan untuk menyesuaikan gambar dengan materi. Hal ini sejalan dengan penelitian Nuryasni (2013) gambar dapat membantu dalam mencapai tujuan instruksional yang telah dirumuskan, karena gambar termasuk media yang mudah untuk mempertinggi nilai pembelajaran. Manfaat gambar dalam proses instruksional adalah penyampaian dan penjelasan mengenai informasi, pesan, ide dan sebagainya tanpa banyak menggunakan bahasa-bahasa verbal, tetapi dapat memberi kesan. Beberapa karakteristik gambar yaitu peserta didik dapat melihat, memahamai dan mengamati melalui gambar, gambar mengurangi kerumitan konsep dan dalam pemilihan suatu gambar harus hati-hati disesuaikan dengan konsep yang telah dipelajari oleh peserta didik.

Adapun saran dan komentar validator materi selanjutnya adalah soal harus dicocokan dengan silabus dan buku laboratorium yang ada di SMA kelas $\mathrm{X}$ dan soal lebih disesuaikan dengan indikator KPS kemudian dilakukan perbaikan untuk indikatornya lebih disesuaikan dengan materi kelas $\mathrm{X}$ semester ganjil. Hal ini dilakukan karena soal yang belum sesuai antara materi yang telah dipelajari dan silabus maupun indikator KPS dapat membuat bingung peserta didik untuk menjawab kunci jawaban yang benar. Pendapat ini didukung oleh penelitian Astuti, Prasetyo, \& Rahayu (2012) bahwa asesmen dilakukan sebagai upaya untuk mengukur tingkat ketercapaian indikator pembelajaran dan mengumpulkan informasi perkembangan belajar siswa pada berbagai aspek. Hal ini juga dijelaskan oleh Utami dan Nurgiyantoro (2016) asesmen digunakan sebagai alat ukur tingkat keberhasilan pembelajaran, dan pencapaian tujuan-tujuan pembelajaran, sesuai dalam kategori taksonomi Bloom soal harus sesuai dengan indikator (artinya soal harus menanyakan perilaku dan materi yang hendak diukur sesuai dengan rumusan indikator dalam kisi-kisi), pengecoh harus berfungsi, dan setiap soal harus mempunyai satu jawaban yang benar (artinya, satu soal hanya mempunyai satu kunci jawaban).

Ahli bahasa memberikan saran yaitu berupa penggunaan tanda baca dan kalimat yang harus diperbaiki dan diperjelas lagi kemudian dilakukan perbaikan pada soal yang kalimatnya kurang efektif guna menghindari kesalahan persepsi peserta didik ketika membaca soal dan agar penggunaan bahasa lebih mudah dipahami oleh peserta didik, sehingga validator bahasa menyarankan untuk merevisi kalimat yang tidak efektif guna untuk kebaikan dalam pembuatan asesmen biologi berbasis KPS. Hal ini sejalan dengan Ayudia, Suryanto, dan Waluyo (2016) dalam menulis kalimat efektif harus memenuhi berbagai syarat. Terkait syarat-syarat kalimat efektif yang harus dipenuhi meliputi kesatuan gagasan, koherensi atau kepaduan yang kompak, kesejajaran atau paralelisme dan kehematan. Diperkuat dengan pernyataan Karyati (2016) berdasarkan konsepsi ejaan tersebut, cakupan 
bahasan ejaan meliputi pemakaian huruf vokal dan konsonan, huruf kapital dan kursif, penulisan dan bentukan kata, penulisan unsur serapan, afiksasi, dan kata asing, dan penempatan dan pemakaian tanda baca. Semua aspek tersebut ditata dalam kaidah ejaan yang disebut Pedoman Umum Ejaan Bahasa Indonesia (PUEBI). Hal ini juga diungkapkan oleh Azwardi dalam Qhadafi (2018) menyatakan fungsi ejaan adalah sebagai landasan pembakuan tata bahasa, landasan pembakuan kosakata dan peristilahan, dan juga sebagai alat penyaring masuknya unsur-unsur bahasa lain ke dalam bahasa Indonesia. Secara praktis, ejaan berfungsi untuk membantu pembaca dalam memahami dan mencerna informasi yang disampaikan secara tertulis.

Saran dari ahli evaluasi berupa perbaiki struktur pertanyaanyang masih dalam bentuk pertanyaan soal essay karena soal pilihan ganda dengan soal essay itu berbeda, kemudian dilakukan perbaikan pada soal dengan merivisi kalimat tanya pada soal pilihan ganda. Karena tidak lazim dalam soal pilihan ganda menggunakan kalimat tanya seperti apakah, bagaimana dan mengapa. Setiap butir soal hanya mengandung satu persoalan/gagasan. Soal pilihan ganda jelas berbeda dengan soal essay, soal pilihan ganda harus memiliki jawaban pengecoh sedangkan untuk jawaban soal essay tidak disediakan jawaban berupa pengecoh tetapi memiliki kunci jawaban berbentuk rubrik dan soal essay yang dituangkan dalam bentuk kalimat yang terstruktur. Pokok soal harus dirumuskan secara jelas dan tegas, artinya kemampuan/materi yang hendak diukur/ditanyakan harus jelas, tidak menimbulkan pengertian atau penafsiran yang berbeda dari yang dimaksudkan penulis. Pendapat ini juga didukung oleh Subali (2012) item berupa suatu pernyataan yang belum lengkap (disebut stem) untuk melengkapinya dengan cara memilih di antara beberapa alternatif/jawaban yang benar disebut kunci, dan yang salah disebut pengecoh (distractor).

Saran selanjutnya dari ahli evaluasi yaitu perbaiki kunci jawaban soal yang panjangnya tidak sama dan cenderung mudah ditebak dan mengarah ke jawaban yang benar setelah dilakukan perbaikan pada soal dengan merivisi bagian kunci jawaban, terdapat perubahan pada kunci jawaban sehingga menuntut peserta didik untuk membaca soal dan dengan teliti, karena soal dengan pilihan jawaban yang tidak sama dapat membuat peserta didik langsung menebak jawaban tanpa membaca soal. Hal ini sejalan dengan penelitian Utami dan Nurgiyantoro (2016) pilihan jawaban harus homogen dan logis ditinjau dari segi materi. Artinya, semua pilihan jawaban harus berasal dari materi yang sama seperti yang ditanyakan oleh pokok soal, penulisannya harus setara, dan semua pilihan jawaban harus berfungsi. Panjang rumusan pilihan jawaban harus relatif sama. Kaidah ini diperlukan karena adanya kecenderungan peserta didik memilih jawaban yang paling panjang karena seringkali jawaban yang lebih panjang itu lebih lengkap dan merupakan kunci jawaban. Pokok soal jangan memberi petunjuk ke arah jawaban yang benar. Artinya, pada pokok soal jangan sampai terdapat kata, kelompok kata, atau ungkapan yang dapat memberikan petunjuk ke arah jawaban yang benar.

Semua saran dan komentar dari validator sudah direvisi. Sehingga dapat disimpulkan bahwa soal biologi berbasis keterampilan proses sains (kps) dapat dinyatakan valid berdasarkan expert judgment (dosen ahli) sehingga dapatdigunakan untuk mengukur keterampilan proses sains (kps) siswa kelas X.

\section{KESIMPULAN}


Karakteristik asesmen yang dikembangakan terdiri dari 50 soal pilihan ganda dan dikembangkan sesuai dengan indikator KPS yaitu mengamati, mengelompokkan, menafsirkan, meramalkan, mengajukan pertanyaan, berhipotesis, merencanakan percobaan, menerapkan konsep dan berkomunikasi. Soal juga dikaitkan dengan silabus Permendikbud No. 37 Tahun 2018 dengan tipe soal pilihan ganda (multiple choice) untuk kelas X. Asesmen biologi berbasis KPS di SMA kota Palembang pada semester ganjil yang dikembangkan sesuai dengan kompetensi dasar (KD) pada materi ruang lingkup biologi, keanekaragaman hayati, virus, bakteri, dan protista.

Kelayakan asesmen oleh validasi ahli aspek materi yaitu 84 dengan kategori sangat valid, validasi ahli aspek bahasa didapatkan skor 80 dengan kategori valid, sedangkan untuk aspek evaluasi didapatkan skor 95 dengan kategori sangat valid. Sehingga dapat disimpulkan bahwa asesmen biologi berbasis keterampilan proses sains di SMA kota Palembang pada semester ganjil layak berdasarkan penilaian para dosen ahli.

\section{SARAN}

Saran yang diberikan terkait asesmen biologi berbasis keterampilan proses sains di SMA kota Palembang pada semester ganjil yaitu: penelitian pengembangan ini hanya sampai pada tahap kelayakan validasi konstruk, maka dari itu untuk penelitian selanjutnya lebih baik bisa dilanjutkan sampai ketahap 10 yaitu melengkapi tes manual (Complete test manual).Penelitian ini dapat dijadikan acuan untuk guru, agar dapat menerapkan soal KPS dan membuat soal berbasis KPS, dan untuk peneliti pengembangan asesmen hendaknya ketika mengembangkan asesmen soal harus memiliki karakteristik yang khas dan berbeda dari soal biasa, seperti contoh asesmen yang dikembangkan dalam penelitian ini memiliki kelebihan dari soal lain karena soal yang dikembangkan disesuaikan dengan indikator KPS dan silabus Permendikbud No.37 Tahun 2018 untuk peserta didik kelas $\mathrm{X}$ semester ganjil, serta menguji kelayakan dari segi materi, bahasa dan evaluasi dari asesmen yang dibuat, untuk memastikan bahwa layak atau tidaknya produk atau asesmen yang dibuat.

\section{DAFTAR RUJUKAN}

Anggiasari, T., Hidayat, S., \& Harfian, B. A. 2018. Analisis Keterampilan Berpikir Kritis Siswa SMA di Kecamatan Kalidoni dan Ilir Timur II. Bioma, 7(2), 184-195.

Aseptianova, Nawawi , S., \& Yuliandina , M. 2019. Pengembangan Asesmen Biologi Berbasis Keterampilan Berpikir Kritis Siswa Kelas XI Semester Genap di SMA Muhammadiyah 1 Palembang. BIOEDUKASI Jurnal Pendidikan Biologi, 10(1), 1-13.

Asih, Triana. 2015. Pengembangan Model Panduan Pembelajaran Keterampilan Proses Sains Biologi SMA/MA. BIOEDUKASI Jurnal Pendidikan Biologi, 6(1), 30-37.

Astuti, W. P., Prasetyo, A. P., \& Rahayu, E. S. 2012. Pengembangan Instrumen Asesmen Autentik Berbasis Literasi Sains pada Materi Sistem Ekskresi.Lembaran Ilmu Kependidikan, 41(1), 40-43.

Ayudia, Suryanto, E., \& Waluyo, B. 2016. Analisis Kesalahan Penggunaan Bahasa Indonesia dalam Laporan Hasil Observasi pada Siswa SMP. Jurnal Penelitian Bahasa, Sastra Indonesia dan Pengajarannya, 4(1), 34-49. 
Iga , A., Fadiawati, N., \& Kadaritna , N. 2015. Pengembangan Instrumen Asesmen Berbasis Keterampilan Proses Sains pada Materi Stoikiometri. Jurnal Pendidikan dan Pembelajaran Kimia, 4(1), 299-311.

Karyati, Z. 2016. Antara Eyd Dan Puebi:Suatu Analisis Komparatif. Jurnal SAP, 1(2), 175-185.

Khairunnisa, Ita, \& Istiqamah. 2019. Keterampilan Proses Sains (KPS) Mahasiswa Tadris Biologi pada Mata Kuliah Biologi Umum. Jurnal Biologi-Inovasi Pendidikan, 1(2), 58-65.

Mulyatiningsih, E. 2011. Riset Terapan Bidang Pendidikan \& Teknik. Yogyakarta: UNYPress.

Nuryasni. 2013. Penggunaan Gambar Dalam Penyajian Soal Cerita Matematika Di Kelas 1 MIN Gunung Pangilun Padang. Jurnal Ilmiah Ilmu Pendidikan, 13(1), 25-33.

Qhadafi, M. R. 2018. Analisis Kesalahan Penulisan Ejaan yang Disempurnakan dalam Teks Negosiasi Siswa SMA Negeri 3 Palu. Jurnal Bahasa dan Sastra, 3(4), 1-20.

Riduwan, M. 2015. Pengembangan Media Pembelajaran Visual Basic Untuk Mengajar Teknik
Pemrograman di kelas X Teknik Elektronika SMK Negeri 1 Sidoarjo. Jurnal Pendidikan Teknik Elektro, 4(3), 863-868.

Rustaman, N. 2005. Strategi Belajar Mengajar Biologi. Malang: Universitas Negeri Malang.

Rustaman, N. 2012. Materi dan Pembelajaran IPA SD. Tanggerang Selatan: Universitas Terbuka.

Subali, B. 2012. Prinsip Asesmen \& Evaluasi Pembelajaran. Yogyakarta: UNY Press.

Sugiyono. 2018. Metode Penelitian Pendidikan (Pendekatan Kauntitatif, Kualitatif, dan $R \& D)$. Bandung: Alfabeta.

Utami, S. Y., \& Nurgiyantoro, B. 2016. Kualitas Soal Dan Daya Serap TePendalaman Materi UN Bahasa Indonesia SMP diGunungkidul. Diksi, 24(1), 5262

Wijaya, E. Y., Sudjimat, D. A., \& Nyoto A. 2016. Transformasi Pendidikan Abad 21 Sebagai Tuntutan Pengembangan Sumber Daya Manusia di Era Global. Prosiding Seminar Nasional Pendidikan Matematika 2016 Universitas Kanjuruhan Malang.1, pp. 263-278. Malang: Universitas Negeri Malang 